\title{
Falares luso-brasileiros no Benim e no Togo: uma abordagem videográfica
}

\author{
Ana Maria Mauad* \\ Vinicius Santos de Medeiros** \\ Rayssa Ramos***
}

O texto videográfico Falares luso-brasileiros no Benim e no Togo insere-se na linha de pesquisa África e Mundo Attântico, do Laboratório de História Oral e Imagem da Universidade Federal Fluminense (LABHOI/ UFF), e tem como objetivo dar subsídios à produção de conhecimento acessível ao grande público sobre as pesquisas desenvolvidas na universidade.

Trata-se de um vídeo de cerca de 20 minutos produzido com base em uma entrevista feita com o antropólogo e fotógrafo Milton Guran, na qual ele apresenta seus estudos sobre os escravos brasileiros retornados à Costa Ocidental da África, os agudás; associadas ao relato, são exibidas as imagens produzidas ao longo de vinte anos de pesquisas de campo.

Entre 2010 e 2012, uma equipe de bolsistas do LABHOI deu início ao processo de digitalização do acervo fotográfico de Milton Guran concernente à sua pesquisa antropológica sobre os agudás, realizada no Benim em 1996 como parte da sua tese de doutoramento. Atualmente, o acervo Agudás, ${ }^{1}$ composto por centenas de fotografias, encontra-se integralmente reproduzido e faz parte do banco de imagens do LABHOI.

\footnotetext{
* Professora associada do Departamento de História da Universidade Federal Fluminense (UFF), pesquisadora do Laboratório de História Oral (LABHOI/UFF) e do CNPq.

** Graduado em história pela UFF, pesquisador do LABHOI/UFF.

*** Graduanda em história pela UFF, pesquisadora do LABHOI/UFF.

1 Em fase de implantação neste endereço: <http://www.labhoi.uff.br/image/tid/193>.
} 
Incorporaram-se a esse conjunto de fotografias outras imagens produzidas entre janeiro e fevereiro de 2010, durante um trabalho de campo feito no Benim para registrar os festejos da burrinha e a missa de Nosso Senhor do Bonfim - eventos anuais em que a identidade social dos agudás, conhecidos como os "brasileiros" do Benim, torna-se pública como marca de diferenciação em relação ao restante da sociedade beninense e como estratégia de superação do estigma da escravidão. $\mathrm{O}$ registro em vídeo - cerca de sete horas de material filmado - resultou no vídeo Falares luso-brasileiros (2013).

Com base em entrevista concedida em 2011 foi composto um roteiro que se distribuiu em blocos temáticos nos quais a narrativa de Guran é entremeada de imagens em movimento que evidenciam traços da tradição e da identidade em ação, promovendo uma descrição visual densa do fenômeno social mediado pelo olhar do pesquisador. $\mathrm{O}$ registro incorporou, na sua fatura, a própria experiência de campo do antropólogo que, desde a década de 1990, colocou o seu olhar a serviço daquela comunidade, pela qual foi recebido com alegria e confiança.

Portanto, apresentamos em Falares luso-brasileiros no Benim e no Togo um tipo de escrita videográfica intertextual, que se utiliza "dos recursos do documentário cinematográfico, interpolando imagens fixas filmadas, cenas filmadas em eventos ao vivo e cenas de entrevistas filmadas. Compóem a narrativa videográfica amúsica incidental, a trilha sonora, a leitura de depoimentos e a fala dos entrevistados" (Mauad, 2010). A elaboração desse texto videográfico, resultado de uma investigação antropológica, enfatizou a relação dialógica entre a pesquisa e a produção audiovisual, contando com a parceria entre historiadores, estudantes de história e de cinema da UFF.

O exercício de relacionar palavras e imagens com base numa reflexão historiográfica reforça o papel da escrita videográfica para a produção de um novo tipo de texto histórico. Um texto que se apoia na produção coletiva e que, por isso, exige a interação de saberes e competências individuais e que incorpora na sua produção a especificidade de enunciação de cada fonte utilizada - fontes visuais e orais. Além, é claro, de potencializar a capacidade da história de criar novos públicos. 


\title{
Referências
}

MAUAD, Ana Maria. Fontes de memória e o conceito de escrita videográfica: a propósito da fatura do texto videográfico Milton Guran em três tempos (LABHOI, 2010). Revista História Oral, v. 13, n. 1, p. 141-151, jan./jun. 2010.

Resumo: Os agudás, conhecidos como os "brasileiros" do benim, descendem de escravos libertos no Brasil que retornaram à África (especificamente Benim e Togo) no século XIX e de negreiros brasileiros estabelecidos no Benim para realizar o tráfico. Atualmente buscam reafirmar sua origem brasileira como marca de diferenciação, representando publicamente a sua identidade étnica e visando anular o estigma da escravidão. O texto videográfico Falares lusobrasileiros no Benim e no Togo apresenta uma narrativa de palavras e imagens, apoiando-se em uma entrevista com o antropólogo e fotógrafo Milton Guran e nas imagens produzidas por ele em seus trabalhos de campo na Costa Ocidental da África desde a década de 1990. Esse vídeo é um importante instrumento didático para o ensino de história da África nas salas de aula do ensino fundamental e médio.

Palavras-chave: identidade, rituais, tradição, memória, escravidão.

\section{Luso-Brazilian Expressions in Benin and Togo: a videographic approach}

\begin{abstract}
The Agudás, known as the "Brazilians" from Benin, are descendants of freed slaves in Brazil who returned to Africa (Benin and Togo) during the 19th century, and the Brazilian slave dealers that had already been established at that region to carry on the slave trade. Nowadays the Agudás try to reassert their Brazilian origin as a symbol of distinction, publically representing their ethnical identity in order to override the stigma of slavery. Luso-Brazilian Expressions in Benin and Togo presents a narrative with words and images based upon an interview with the anthropologist and photographer Milton Guran and the images produced by him during his fieldwork in the West Coast of Africa since the 1990s. This video is an important didactical instrument for the teaching of African History for elementary and high school students.
\end{abstract}

Keywords: identity, rituals, tradition, memory, slavery.

Recebido em 20/04/2013

Aprovado em 30/05/2013

\author{
Acesso ao filme em: \\ http://ufftube.uff.br/video/891NW4ADKGM5/Falares-Luso- \\ brasileiros-no-Benim-e-Togo
}




\section{Ficha Técnica}

\section{Produção: LABHOI}

Coordenação: Ana Maria Mauad

Pesquisa acadêmica, registro videográfico e registro fotográfico: Milton Guran

Edição: Eduardo Cantarino, Rayssa Ramos

Assistente de edição: Vinícius Medeiros

Roteiro: Ana Maria Mauad, Milton Guran, Vinícius Medeiros

Câmera extra: Guilherme Garcia 